La Lepro 44, 4 (1975)

\title{
Follow-up Study of the Patients with Hansen's Disease in Kyoto Prefecture
}

\author{
HIDEO TAKIZAWA \\ (Leprosy Research Laboratory, Kyoto University) \\ Susumu ADACHI, Kentaro MATSUMOTO and TARo KAKITANI \\ (Department of Health, Kyoto Prefecture)
}

Fifty five cases of all 64 out-patients with HD in Kyoto Prefecture could be followed up. (Eleven cases of them were dead. Two cases were readmitted to leprosaria.) Their ages ranged from 28 years to 88 years (mean 54.3). About $61 \%$ of them were over 50 years old.

Eight cases of 30 lepromatous or borderline cases $(26.7 \%)$ experienced relapse in their course. The period of time from bacterial negativity to relapse were 3 years to 13 years. Some troubles of patients and the control problem of HD in Japan was discussed briefly.

\section{京都府におけるハンセン病在宅者の実態調査}

\author{
瀧 澤 英 夫 \\ (京都大学医学部皮膚病特別研究施設)

足立 晋 松 本 顕 太 郎 柿 谷 太 郎

（受付 1975 年 6 月 2 日）

\section{I. はじめに}

厚生省結核予防課（現，結核成人病課）が行った「ら い在宅患者実態調查報告書」1) よよれば, 昭和 43 年 12 月 3 日現在での，いわゆる在宅患者の年齢階級別の最頻値は 男女とも50 59歳であった。なお，50歳以上の在宅患者 数は 416 名で，全体の $65.3 \%$ を占めるほど老齢化してい ることを示している。

現行の「らい予防法」の下における「在宅患者」の定 義は極めて不明確であるが，ここでは昭和 32 年11月に発 表された，結核予防課滝川勝人氏の定義を借用しておく ことにする。氏によれば「らい患者として各都道府県の 衛生局に把握されてはいるが，療養所に入ることなく常 に入所勧奖，健康診断など，らい予防行政の対象となっ
ている患者2」，を在宅患者といっている。

現行の予防法は在宅患者の医療を積極的にはかる方策 を全く欠いている。そのため結核におけるような在宅患 者の医療面の指導区分（要医療, 医観察, 観察不要）が なく, 各都道府県における在宅患者の療羑指導に一貫し た方針がたてられていないのが現状である゙3。「らい予 防法」成立以来すでに 20 余年を経て扔り，ハンセン病医 療の進歩を土台にして在宅患者に対する積極的な取り組 みが要請されており, 著者の一人は機会ある毎にその必 要性を強調してきた(4)5)。

京都府においても新患発生の著減とともに（第 1 図)，こうした在宅患者の老龄化に伴う問題（医療上の 問題に限らない）が少しずつ顕在化してきた。こうした 実態を身をもって受けとめ，将来に対する方策をたてる 


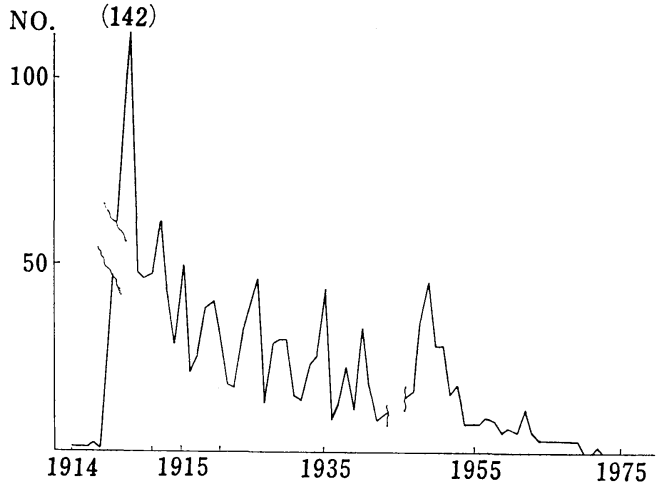

Fig. 1 New cases in Kyoto

資とするために「らい予防法」の谷間で苦闑している人 たちの現況調査が計画された。

\section{II. 調查の方法}

計画の主体は京都府衛生部であり, 京都大学医学部皮 膚病特別研究施設（以下京大とする）がこれに協力する 形で調査が行われた。対象はかってハンセン病を病み, あるいはなお病をもちながら社会生活をしている京都在 住の64名である。調查は可能な限り，これらの人たちを 生活の中でとらえようと，府職員と医師とが一組となり
患家を訪問することを原則とした。訪問診査の内容はハ ンセン病医療に限らず，一般医療の受診状態や生活上の 諸問題全般についても相談を行うこととした。 京都府では昭和28年の「らい予防法」の施行以前より 京大においてハンセン病患者の治療がすでに行われてい たために，在宅患者の把握は主として京大における診療 を通じてなされてきたといえる。この点が他府県と異る 特異な点であろう。そのため療養期間が長かった患者ほ ど，ハンセン病の医療行政について国や府県に対する不 信感はわれわれの想像以上に強い。彼等の心にきざみつ けられた傷痕は深く, 容易に癒されていない。そのため こうした調査, とくに訪問診査の第一の险路は在宅者へ のアプローチであった。長い間京都府の担当官であった Y氏がその人柄によって作りあげた患者やその家族への ラポールは公の記録に全くとどめていない。そのため今 回の診查は京大における医療関係を媒介として，新たな アプローチを求めなければならなかった。

実施方法は両者が再三打合せ会を持って検討し，第 2 図のような連絡文書を個人名で昭和 47 年末に対象者に送 った。

調査の期間は昭和 48 年 1 月から 50 年 3 月末まで 2 年余 にわたっており，その仕事はゆっくりと根気よくなされ
厳しい寒さが続いて年末の慌しい日々ですが，お元気 に打暮らしのことと推察いたし，およろこび申しあげま す。

平素は貴殿のお暮らしのことを気にしつつ執務いたし でおりますが, 今般, 京都大学,

諸先生 のご協力を得まして, その後の健康状況, 暮らしの相談 等について日時を定めて巡回相談を実施することになり ましたので，貴殿のご希望を予めお聴きしたうえ，実施 したいと考えております。

つきましては，年末なにかとご多用のところ恐縮です が，別紙ご記入のうえ，ご返送くださいますようよろし くお願いします。

昭和 47 年 12 月 日

殿

京都狩衛生部保健予防課長

なお，返送の場合は，同時の封筒をご使用ください。
(別紙) おなまえ

殿

おたずね（該当，希望されるところを○でか こんでください

○相談日は 1 月下旬か 2 月上旬のいずれを希望さ れますか。（特に指定される日があれば月日 午前, 午後)

○相談の場所は，つぎのいずれを希望されますか。 （希望されるところを○でかこんでください。）

(イ）自宅

（口）保健所(住所地の)（京都市内は除く）

(八) 京都大学

（二）その他(具体的に，簡単な目標物)

○現在貴殿が生活上心配していることを記入してく ださい。

○今後の連絡方法 手紙の場合 住 所

$$
\text { あて名 }
$$

電話の場合局 番

Fig. 2 Letter to patients 
た。

\section{III. 調査結果と考察}

（1）対象者は京大ならびに府衛生部の資料から在宅患 者および在宅者（この区分は厳密なものではない。医療 区分は後述する）とし，第 1 表のような 64 名が選ばれ た。対象者の病型病勢は厚生省化学療法研究班の判定基 準6) に準拠したが，病型については国際分類に準じて, $\mathrm{B}$ と I を区別した。年㱓階級別では70歳以上に最頻值を もつが，50歳以上が $60.9 \%$ を占める（第 2 表）。

Table 1 Type and Stage of patients

\begin{tabular}{c|crr|r}
\hline \hline Stage & $\begin{array}{l}\text { Progre- } \\
\text { ssive }\end{array}$ & $\begin{array}{l}\text { Retrogr- } \\
\text { essive }\end{array}$ & $\begin{array}{l}\text { Quiescent/ } \\
\text { Arrested }\end{array}$ & Total \\
\hline Type & 1 & 11 & 18 & 30 \\
B & & 3 & 3 & 6 \\
T & & 1 & 24 & 25 \\
I & & & 3 & 3 \\
\hline Total & 1 & 15 & 47 & 64 \\
\hline
\end{tabular}

Table 2 Age distribution

\begin{tabular}{|c|c|c|c|c|c|c|c|}
\hline Age & $\begin{array}{l}20 \\
\sim 29\end{array}$ & $\begin{array}{l}30 \\
\sim 39\end{array}$ & $\stackrel{40}{\sim} 49$ & $\stackrel{50}{\sim} 59$ & $\stackrel{60}{\sim 69}$ & $70 \sim$ & Total \\
\hline Male & 4 & 2 & 9 & 7 & 10 & 11 & 43 \\
\hline Female & 2 & 3 & 5 & 4 & 3 & 4 & 21 \\
\hline $\begin{array}{c}\text { Total } \\
(\%)\end{array}$ & $\begin{array}{c}6 \\
(9.4)\end{array}$ & $\begin{array}{c}5 \\
(7.8)(\end{array}$ & $\begin{array}{c}14 \\
(21.9)\end{array}$ & $\begin{array}{c}11 \\
(17.2)\end{array}$ & $\begin{array}{c}13 \\
(20.3)\end{array}$ & $\begin{array}{c}15 \\
(23.4)\end{array}$ & $\begin{array}{c}64 \\
(100)\end{array}$ \\
\hline
\end{tabular}

Table 3 Reply to the Letter

\begin{tabular}{cr}
\hline \hline Reply & 23 \\
OK & 6 \\
Wish to go to clinic & 14 \\
No wish & 1 \\
Dead & 2 \\
No Reply & 26 \\
Return & 15 \\
\hline
\end{tabular}

（2）前述した手紙の返信は第 3 表のように予想された 結果となった。返信のあったもののうち, 訪問 可は 6 名，京大外来を希望するもの 14 名，Wずれとも可は 1 名，死亡を通知してきたもの 2 名であった。残りの 41 通 のうち，返信はなかったが手紙が到着したと想像される もの 26 通，居所不明で返送されてきたのが15通である。 以後は京大外来を希望するものは診察後に改めて面接
を行い，自宅を希望するものは訪問して生活の場で診察 や相談を行った。返送分については居住地の確認から調 查をすすめた。

（3）昭和50年 3 月末の段階での調査結果を第 4 表以下

Table 4 Results

(1) Contact

\begin{tabular}{lr}
\hline \hline Contact & 44 \\
Dead & 11 \\
No Contact & 9 \\
\hline
\end{tabular}

に示す。担当者の努力で総数64名中，面接可能のものは 44名（うち 2 名は転居して他府県に居住）, 居所不明で 面接できなかったものは 9 名（うち1名は転居を確認）, 残り11名は死亡が確認された。すなわち， 64 名中 55 名 (85.9\%) の追跡調査ができた（第 4 表）。

Table 5 Results

(2) Condition of Disease

\begin{tabular}{lc}
\hline \hline Stable & 40 \\
Worse & 3 \\
(Readmitted & $2)$ \\
\hline
\end{tabular}

（4）病状の動きは第 5 表に示されるように，調查時点 からみて悪化せるもの 3 名（うち1名は合併症と経済的 理由により再入所)。再入所の他の 1 名はその他の理由 によるものである。病状悪化は $\mathrm{Lq} \rightarrow \mathrm{Lp}, \mathrm{Lq} \rightarrow \mathrm{Lr}, \mathrm{Lq}$ $\rightarrow \operatorname{Lr}$ の 3 名である。

Table 6 Results

(3) Type and stage of patients

\begin{tabular}{c|rrr|r|r}
\hline Stage & $\begin{array}{l}\text { Progr- Retro- } \\
\text { essive }\end{array}$ & $\begin{array}{c}\text { Qniescent } \\
\text { gressive }\end{array}$ & $\begin{array}{c}\text { Arrested } \\
\text { Contact }\end{array}$ & Total \\
\hline L & 1 & $8^{*}$ & 16 & 3 & 28 \\
B & & 2 & 3 & 1 & 6 \\
T & & & 13 & 3 & 16 \\
I & & & 1 & 2 & 3 \\
\hline Total & 1 & 10 & 33 & 9 & 53 \\
\hline
\end{tabular}

* Two of 8 re-admitted.

死亡の11例を除いた調査終了時点の対象者の病型, 病 勢は第 6 表に示される。第 1 表と比較されれば分るよう に, 死亡例は L で 2 例, $\mathrm{T}$ で 9 例。病状の動きは $\mathrm{T}$ 型と I 群ではなく，L型やB 群にみられるのが特徽である。 L型と B 群の病状の動きは複雑であり, 長期観察の一端 
Table 7 Results

(4) Lepromatous and Borderline Cases

\begin{tabular}{|c|c|c|c|c|c|c|c|}
\hline \multicolumn{2}{|c|}{ Case } & \multirow{2}{*}{$\begin{array}{l}\text { Start of } \\
\text { Treat. }\end{array}$} & \multirow{2}{*}{$\begin{array}{l}\text { Admission to } \\
\text { Leprosarium }\end{array}$} & \multirow{2}{*}{$\begin{array}{l}\text { BCT'1) } \\
\text { (yrs) }\end{array}$} & \multirow{2}{*}{$\underset{(y r s)}{\text { Relapse }^{2)}}$} & \multirow{2}{*}{$\begin{array}{c}\text { Treatment \& } \\
\text { Follow-up }\end{array}$} & \multirow{2}{*}{$\begin{array}{l}\text { Type \& } \\
\text { Stage }\end{array}$} \\
\hline Age & Sex & & & & & & \\
\hline 45 & $\mathrm{~F}$ & 1953 & No & 12.1 & 9 & reg. & $\mathrm{Lp}$ \\
\hline 44 & $\mathrm{~F}$ & 1941 & No & - & - & irreg. & $\mathrm{Lr}$ \\
\hline 63 & $\mathrm{M}$ & 1943 & Yes & - & - & irreg. & $\mathrm{Lr}$ \\
\hline 47 & M & 1951 & Yes & - & $13^{*}$ & irreg. & $\mathrm{Lr}$ \\
\hline 44 & $\mathrm{M}$ & 1952 & Yes & - & $6^{*}$ & irreg. & $\mathrm{Lr}$ \\
\hline 49 & M & 1954 & Yes & - & $10^{*}$ & irreg. & $\mathrm{Lr}$ \\
\hline 40 & $\mathrm{M}$ & 1955 & Yes & - & - & irreg. & $\mathrm{Lr}$ \\
\hline 31 & $\mathrm{M}$ & 1956 & Yes & - & $11^{*}$ & irreg. & $\mathrm{Lr}$ \\
\hline 50 & $\mathrm{M}$ & 1961 & Yes & - & - & irreg. & $\mathrm{Lr}$ \\
\hline 65 & $\mathrm{M}$ & 1940 & No & - & - & irreg. & $\mathrm{Lq}$ \\
\hline 48 & $\mathrm{~F}$ & 1947 & No & 8.6 & - & reg. & $\mathrm{Lq}$ \\
\hline 67 & $\mathrm{M}$ & 1951 & Yes & - & - & irreg. & $\mathrm{Lq}$ \\
\hline 39 & $\mathrm{~F}$ & 1952 & No & 5.3 & - & reg. & $\mathrm{Lq}$ \\
\hline 58 & $\mathrm{~F}$ & 1952 & Yes & 6.0 & - & reg. & $\mathrm{Lq}$ \\
\hline 72 & $\mathrm{M}$ & 1953 & No & 6.6 & - & reg. & $\mathrm{Lq}$ \\
\hline 61 & $\mathrm{M}$ & 1953 & Yes & 8.8 & - & irreg. & $\mathrm{Lq}$ \\
\hline 47 & $\mathrm{M}$ & 1954 & No & 7.6 & - & reg. & $\mathrm{Lq}$ \\
\hline 49 & $\mathrm{~F}$ & 1956 & No & 5.0 & - & reg. & $\mathrm{Lq}$ \\
\hline 49 & $\mathrm{M}$ & 1958 & Yes & - & - & irreg. & $\mathrm{Lq}$ \\
\hline 45 & M & 1958 & Yes & 6.0 & - & reg. & $\mathrm{Lq}$ \\
\hline 66 & $\mathrm{M}$ & 1958 & No & - & - & reg. & $\mathrm{Lq}$ \\
\hline 63 & $\mathrm{M}$ & 1958 & Yes & 5.0 & - & irreg. & $\mathrm{Lq}$ \\
\hline 27 & $\mathrm{~F}$ & 1962 & Yes & 9.1 & - & reg. & $\mathrm{Lq}$ \\
\hline 55 & $\mathrm{M}$ & 1965 & Yes & 6.9 & - & reg. & $\mathrm{Lq}$ \\
\hline 24 & $\mathrm{M}$ & 1965 & Yes & - & - & reg. & $\mathrm{Lq}$ \\
\hline 65 & $\mathrm{~F}$ & 1954 & Yes & 13.9 & 5 & reg. & $\mathrm{L} \rightarrow \mathrm{Br}$ \\
\hline 53 & $\mathrm{~F}$ & 1954 & Yes & - & $10^{*}$ & irreg. & $\mathrm{L} \rightarrow \mathrm{Br}$ \\
\hline 33 & $\mathrm{M}$ & 1961 & No & 2.1 & - & reg. & $\mathrm{Bq}$ \\
\hline 67 & $\mathrm{M}$ & 1963 & No & 2.0 & 3 & reg. & $\mathrm{Bq}$ \\
\hline 49 & $\mathrm{~F}$ & 1963 & Yes & - & - & reg. & $\mathrm{Bq}$ \\
\hline 29 & $\mathrm{~F}$ & 1965 & No & 0.3 & - & reg. & $\mathrm{Iq}$ \\
\hline
\end{tabular}

1) BCT: Bacterial Clearance Time, the period of time (years) from the start of treatment to negativity of bicilli in skin smears.

2) Relapse: The period of time (years) from bacterial negativity to relapse.

*) The period of time (years) from discharge of leprosarium to relapse.

を表にまとめると第 7 表になる。

（5）第 7 表を要約すると次のようなことが分った。年 齢は24歳から72歳までで, 治療および観察期間は 9 年か ら34年に及ぶ。入所歴を有する者は 30 例中 19 例（63.3 \%）と半ば以上を占めている。しかし入所歴の有無は治
療開始年次に必しも並行しない。すなわち，かっては入 所をすすめ, 最近では外来あるいは入院治療を主体とし ているとはいえない。これは京都府の新患が最近著減し ている（第 1 図）ことと関係があろうが，患者の病状や 生活状態により治療方法の選択を行っていたと考えたほ 
うがより実状に近い。BCT は化学療法における臨床的 治瘾の一つの指標として作られたもので7)，治療の開始 から皮膚の菌陰転化までの期間を示す。全例から有用な 検查成績が得られなかったが, I 群やB 群に比してL型 における BCT の延長がみられ，BCT による群分けで は7) 標淮減少群 7 例と遅延減少群 6 例が得られた。なお 10年以上治療を続けているが，未だ菌陰転化をみない症 例が 4 例も認められることが注目される。

再発（臨床的治癒に達した症例に再び皮疹が出現し菌 が陽性に検出される）は30例中 8例 (26.7\%）に認めら れた。再発は 3 年から 13 年の後に出現したことは後述す るように, 長期間の follow-up の必要性が強調される。 L型の再発皮疹が $\mathrm{B}$ 群に属する症例が 2 例認められた。 治療および経過観察は入所歴のある患者の方が不規則 になりがちである（危険率 $5 \%$ ）が，不規則になる条件 が患者側にすべてあるとはいえない。療養所と外来診療 施設との密接な有機的なつながりのない現在, さらに言 えば予防法下の不安定な外来診療に問題があるとも考え られよう。

Table 8 Results

(5) Disabilities in Leprosy patients

\begin{tabular}{cc}
\hline \hline Grades $1 \sim 5$ & Grades $2 \sim 5$ \\
22 & 20 \\
\hline
\end{tabular}

（6）四肢ならびに顔の障害度を WHO の基準8)に基 いて段階分けをすると第 8 表のようになる。

(7) 死亡の11例はすべて家族にみとられてこの世を去 ったことが確められた。生存者のらちで，ハンセン病医 療（再発の不安を含めて）を含めていまの心配なことを 表示すると第 9 表のようになる。医療的な問題はハンセ

Table 9 Results

(6) Patient's troubles

\begin{tabular}{lr}
\hline \hline Medical for H.D. & 14 \\
Medical for others & 5 \\
Socio-economical & 8 \\
\hline
\end{tabular}

ン病とその他の疾患に分けられる。ハンセン病に対して は再発の心配や現在治療中の病気が本当に治癒するかな どである。固定された後遺症などの障害を持った人たち は一般医療機関を容易に利用し得ない。この点の問題は 後者に含まれるが, 第 8 表でみられる障害者の割合に対 乙問題が比較的少いのが注目される。在宅治療の大きな 利点であろう。社会経済的な問題は一般の社会福祉の枠
の中で解決できることが望ましい。老人の一人暮しで, 障害を持った人たちの問題が最も大きい。不充分な社会 福祉のために, 入所歷のない老人が入所を望むという逆 コースや, 社会経済的事由のみで再入所を望む症例にわ れわれはすでに直面している。

（8）結核予防法を参考にしながら，われわれは在宅患 者の療養指導区分を次のように提案したい。

1. 要治療: すべての病型を通じて, 未だに臨床的治 㾍に達せず，ハンセン病医療を必要とする患者。臨床的 治癒とは「非活動性の期間が 2 年以上にわたるものにつ いて, 病理組織検査を行ない, その結果を参考として決 める。光田反応が陽転することが望をしい」（らい調查 会, 活動性区別による)

2. 要観察 : 臨床的治漓に達した患者のうち, 再発の 恐れのあると認められる者。病型別では $\mathrm{L}$ 型や $\mathrm{B}$ 群の回 復者の多くはここに含められる。T 型や I 群 の回復者 で, 種々の障害の経過観察が必要な者や一般医療機関へ の受診が困難な者も含まれよう。

3. 観察不要（登録除外）：治療や観察を必要としな い回復者。

第 1 群を在宅患者, 第 2 群と第 3 群を回復者（在宅） と呼ぶことができよう。京都府の対象者をこの 3 群に分 けると第10表になる。

Table 10 Results

(7) Classification of patients by proposed leposy control programme in kyoto

Registered cases

$$
\text { under treatment }
$$
under observation

Released cases from control 12

Out of control cases 9

（9）在宅患者の現状と今後の問題点 : 京都府の在宅患 者の実態調查を通じて得られた結果より, 日本の在宅患 者の現状と問題点を以下に列挙する。

1. 在宅患者の実態は全国的に充分把握されていな い。厚生省の炤和 43 年 12 月 31 日現在における「らい在宅 患者実態調查報告」1)では，都道府県に 登録されている 在宅の患者を対象としているにすぎない。現行法の許で は在宅患者の定義付けが不明確なために, 例えば療養所 からの退所者の動態がつかめていない。また，在宅患者 の移動，とくに大都市へのそれについては各府県間ある いは施設と府県の間の連絡が不充分であるため僅かに把 
握されているにすぎない。

2. 新患発生が沖繩などの一部の地域を除いては著減 している。そのため在宅患者は年々老齢化の傾 向を辿 る。

3. ハンセン病の治療を必要とする在宅患者は一部の 新患を除いては，長期の再燃あるいは再発患者にしぼら れてくる。

4. L型やB 群の再発率は決して低くない。再発を予 想される回復者に対しては, その再発を予防し, 安心し て社会生活を続けていく支えとなる follow-up system が必要である。

5. 障害の少ないT型やI 群の回復者には医療上や社 会生活上の問題は少い。

6. 障害を持った回復者のらちで，医療面あるいは社 会福祉面でその枠外に落ち込む恐れが大きい人たちがい る。

7. 今後のハンセン病の外来診療施設は上記の 3,4 の医療面のみならず， $3 ， 6$ の福祉面の支えとなる役割 が必要となる。

8. 今後行われる実態調查も対象となる人たちの医療 と福祉の向上に資する11) ため行われるべきである。

\section{IV. まとめ}

京都府におけるハンセン病在宅者 64 名の実態調査を行 い，次のような結果を得た。

1. 64名中55名 (85.9\%) の追跡調查ができた。55名 の中には11名の死亡，2名の再入所者が含まれている。

2. 年齢は 28 歳から88歳までで, 平均年齢は 54.3 歳で ある (昭和 50 年 3 月末現在)。 50 歳以上が約 $61 \%$ を占め ている。
3. ᄂ型と B 群の患者30例中 8 例 $(26.7 \%)$ に再発が 認められた。

4. 入所歷のある在宅患者の方がない者より治療や経 過観察が不規則になりがちである。

5. WHO の基準による障害度（2 度以上） は 47.6 \%である。

6. 医療や生活上の切実な悩みが27件（25名）訴えら れた。

7. 在宅患者の療養指導区別として, 要治療, 要 観 察, 観察不要の 3 つに分け, 第一群を患者, 第 2 群以下 を回復者と呼ぶことを提案した。

8. 日本の在宅患者の現状と問題点に言及した。

\section{文献}

1）厚生省結核予防課：らい在宅患者実態調查報告 書, 1-37, 厚生省 (1970).

2）滝川勝人：在宅らい患者の実態レプラ， 26, 349-361 (1957).

3) 石原重徳, 他：愛知県における“らい”の外来 診療10年のあゆみ, レプラ，43，97-101(1974).

4）滝沢英夫：ハンセン病の外来診療，多磨， 54 , 2-12 (1973).

5）滝沢英夫：らい予防法の問題点一外来診療を行 っている立場から，レプラ，43，85-86 (1974).

6）厚生省化学療法研究班：ら以病勢並治妕判定基 準, レプラ，37，270-272 (1968).

7）滝沢英夫：化学療法によるハンセン病の臨床経 過㧍よび予後の研究，（1）らい腫型に打ける菌 の消長, レプラ，43，275-283 (1974).

8) WHO Expert Committee on Leprosy: Classification of Leprosy Disabilities, Wld Hlth. Org. techn. Rep. Ser., 319 (1966). 